\title{
REFLECTING SUSTAINABILITY IN PROPERTY VALUATION - DEFINING THE PROBLEM
}

\author{
Ewa Kucharska-Stasiak, prof., Ph.D. \\ Department of Investment and Real Estate \\ University of Lodz \\ e-mail:ewkuchar@uni.lodz.pl
}

\author{
Katarzyna Olbińska, M.Sc. \\ Department of Investment and Real Estate \\ University of Lodz \\ e-mail:katarzyna.olbinska@uni.lodz.pl
}

\begin{abstract}
A major topic in discussions about environmental protection is the concept of sustainable development utilizing the economic criteria enhanced by environmental, social and ethical aspects. The concept inspired a new approach to construction and paved the way for the idea of sustainable buildings. Sustainable buildings are expected to offer economic benefits to their owners and tenants that should be reflected in property values. The authors test a hypothesis that the real estate market in Poland still fails to incorporate sustainability in property valuation. The article seeks evidence in support of this hypothesis, as well as attempting to find out why the market does not pay a premium for sustainability. To accomplish the purpose of the research, a systematic literature review, an analysis of the pilot studies available in Poland and a preliminary assessment of the ability of valuation methods to reflect sustainability in property valuations are performed. The focus of the research is on the office property market, one of the fastest growing and most modern segments of the real estate market. The conclusion drawn from the research is that, of all respondents surveyed by international studies, Polish developers, property owners, tenants and valuers know the least about sustainable building and that the evidence of the benefits of sustainable building is still unavailable in the Polish real estate market. Such benefits are rather hypothesized to exist and considered theoretically rather than empirically confirmed. It is possible that the reasons for these findings are the short period of research and problems with distinguishing sustainable buildings from conventional ones, which make it difficult for valuers to reflect the benefits of sustainability in valuations. Nevertheless, a new approach to property valuation encompassing environmental, ethical and moral aspects seems necessary. This would encourage sustainable building and green investment strategies. Sustainable valuation would also be an opportunity for the development of the valuation profession.
\end{abstract}

Keywords: property valuation, sustainability, green building.

JEL Classification: R30, D03, D70.

Citation: Kucharska-Stasiak E., Olbińska K., 2018, Reflecting Sustainability in Property Valuation Defining the Problem, Real Estate Management and Valuation, vol. 26, no. 2, pp. 60-70.

DOI:10.2478/remav-2018-0016

\section{Introduction}

Market participants are increasingly aware of the importance of environmental quality and of the scarcity of natural resources. The process is accompanied by the evolution of value systems towards 
placing greater emphasis on corporate social responsibility, sustainable development ${ }^{1}$ and responsible investment strategies. The issue of environmental protection was already tackled in the late sixties early seventies of the $20^{\text {th }}$ century in the U Thant, UN Secretary-General report (1969) and the Club of Rome Report (1972). In 1972, terms such as "ecodevelopment" and "environmental protection policy" were introduced to public debate. In 1987, the United Nations published the Brundtland Report calling for global environmental action. Three years later, in 1990, the conference of the member states of the United Nations Economic Commission for Europe (UNECE) adopted permanent sustainable development as a guideline for Europe (ZBIERSKA 2007, pp. 275-281). The European Union, too, shows its concern for sustainability issues. Although real estate is immovable by definition and is not specifically regulated, EU treaties and legislation indirectly influence this market segment through the Community's environmental policy that keeps improved energy efficiency of buildings at the top of the agenda ${ }^{2}$. The rising consumption of fossil fuels ${ }^{3}$ also necessitates a rapid reorientation of our attitudes.

From the above it follows that the real estate decisions should be made with concern for economic criteria as well as for the social, environmental and ethical aspects. This attitude leads to sustainable building, the development of which depends not only on the market participants' awareness of sustainability issues and their readiness to embrace the concept of sustainable development, but also on the benefits that property owners and tenants can have from sustainable building, which should be reflected in valuations. The idea of sustainable development was taken up by the international real estate community, leading to the adoption of the Vancouver Valuation Accord in 2007. In the Accord, the community undertook to advance the understanding, education and practices of valuation according to the principles of sustainable development (ARMITAGE 2009, p. 10).

\section{Research goal and hypothesis}

The purpose of real estate valuation is to determine, or more precisely to predict, the price that the market would pay for a property on the valuation date. This means that EU's environmental initiatives or laws have no bearing on valuations unless they are implemented by the local market. This leads to an interesting question about whether sustainable buildings are awarded a premium for being sustainable. In this article, a hypothesis is tested that the Polish real estate market has not yet embraced the concept of sustainability. The following analysis will seek to answer two questions: "is this really so?" and, if the answer is yes, "why?"

To this end, we shall analyze:

- the degree to which developers, investors, principal tenants and valuers are aware of the benefits of sustainable building,

- whether operating expenses provide evidence that such benefits are achievable.

The focus of the analysis will be on the office property market, one of the fastest growing and most modern segments of the real property market. An assumption is made that premiums for "green buildings" are higher in this market than in other market segments (NAPPI-CHOULET, DECAMPS 2012, p. 17).

\section{The directions of research into sustainable buildings to date}

Studies on sustainable buildings fall into three main areas:

1) market transparency regarding the sustainability of buildings,

2) the benefits of sustainable buildings,

3) the capability of the current valuation methods to reflect sustainability in property valuation.

\footnotetext{
1 The concept of social responsibility and sustainable development establishes a new economic paradigm interpreted as the need for flows (human, natural, financial and real) to be harmonised with what is required to maintain dynamic equilibrium, with the real possibilities of economic growth. See KOŁODKO 2014.

2 A reflection of this policy can be found in successive directives issued by the European Parliament and European Council. The last of them - the 5th Energy Efficiency Directive - was adopted on 25 Oct. 2012. It set a target of $20 \%$ reduction in the annual consumption of energy by the end of 2020 . The EU focuses its efforts on improving efficiency at every stage of the energy chain, from the supply of energy to its consumption by final users. Of special concern is the energy efficiency of buildings that account for $36 \%$ of carbon dioxide emissions. ${ }^{3}$ Fossil fuels consumed between 1970 and 2014 constituted $58.5 \%$ of the coal used in the history of humankind, $81.5 \%$ of crude oil and $90.9 \%$ of natural gas (POPKIEWICZ 2015, p. 22)
} 
In 2012, Jones Lang LaSalle included sustainability in its real estate transparency index, a decision reflecting the growing importance of sustainability in making investment decisions about real estate. The JLL's Global Real Estate Transparency Index is based on 28 national markets analyzed with respect to the use of energy-efficient solutions and sustainable building rating systems. The index divides countries into four categories: highly-transparent markets, transparent markets, semitransparent markets and low transparency and opaque markets. The most transparent markets regarding sustainability are those of the UK, Australia and France. Poland is classified among the semi-transparent markets (THE GLOBAL REAL ESTATE TRANSPARENCY INDEX...).

Within the second area of research, the characteristics of sustainable buildings and the benefits of having, operating and using them are analyzed. The definition of a sustainable building that draws on the definition of sustainable development is still evolving (MYERS et al. 2007, p. 2). According to the EUROPEAN VALUATION STANDARDS (EVS) "a "green" or "sustainable building" uses resources such as energy, water, materials and land more efficiently than buildings constructed to existing minimum standards, producing less waste and fewer emissions, and potentially offering a better internal working environment, benefiting health comfort and usefulness. As the concept of sustainability expects that the needs of the present should not compromise the ability of future generations to meet their own needs, green buildings should also take social, ecological and environmental issues into account. That broader definition includes external effects and the impact across generations, and so the property's life cycle" (EVS 2016, p. 254).

The concept of building sustainability neither is nor can be precise, because buildings and their functions are very diverse, as are the expectations of their users that additionally change over time.

This definitional ambiguity causes problems with distinguishing between green buildings and conventional buildings. In assessing the sustainability of buildings, the EVS relies mainly on sustainability rating (certification) systems, such as BREEAM, LEED, DGNB, HQE, CASBEE, Green Star or NABERS. According to the EVS (2016, pp. 255-256), there are around 30 voluntary certification systems, which are being fine-tuned by their authors to better reflect the complexities of sustainability. In this article, a sustainable (green) building is understood as one meeting sustainability criteria established by certification systems such as BREEAM, LEED, DGNB, HQE, CASBEE, Green Star or NABERS.

The criteria refer to:

- energy efficiency,

- limited environmental impacts,

- high functionality and quality of utilities/services, durability and adaptability to market requirements,

- ease of maintenance and of waste recycling,

- high comfort and better well-being of the users.

Table 1 presents benefits that may come with sustainable buildings.

Amid the variety of benefits, those available to property owners and tenants can be identified. In the first case, the direct economic benefits include higher operating income (because of higher rents, lower operating costs, better occupancy rates or reduced insurance cost) while the indirect economic benefits are represented by higher resistance of the building to functional obsolescence and lower income risk. The first of the two factors also promises greater income and value stability (MCNAMARA 2008, pp. 41-43). From the tenant's perspective, the direct economic benefits are lower operating costs, and the indirect ones include lower employee absenteeism and turnover rates, higher productivity, a better public image of the company and the presentation of itself as a socially responsible organization (EICHOLTZ et al. 2010).

The ESV definition of a sustainable building operates on a range of complex environmental, financial and social criteria, which shows that the concept of sustainability is not limited to energy efficiency alone. These complex criteria are related to the requirements of the building certification systems and played a role in the formulation of the European Valuation Standards. TEGoVA adopted sustainability as one of the factors determining the class of a building and attributed it with a weight of $10 \%$ (EVS 2016, pp. 335-343). It also recommends that sustainability, especially energy efficiency, be considered in the valuation process (EVS 2016, pp. 149-159). TEGoVA standards provide that "energy costs and efficiency" influence market value so they are "one of many issues for the valuer to take into account" (EVS 2016, p. 151), and that the weight given to this factor "... will be a matter for the professional skill of the valuer" (EVS 2016, p. 157). This approach turns valuers into conscious players 
in a market focused on sustainable development. Both valuation and valuers are considered important in promoting sustainability and the idea of sustainable development. On the one hand, valuers should reflect in the value of a property, understood as a hypothetical price, the property's competitive characteristics, and on the other hand, the value itself should confirm the benefits of a sustainable building to promote and encourage sustainability. The requirement for the valuer to highlight sustainability in the valuation process arises from corporate social responsibility. Unfortunately, the adoption of this concept in valuation practice is impeded by inherent barriers (MYERS et al. 2007, p. 1$)^{4}$.

Table 1

Some benefits of sustainable buildings

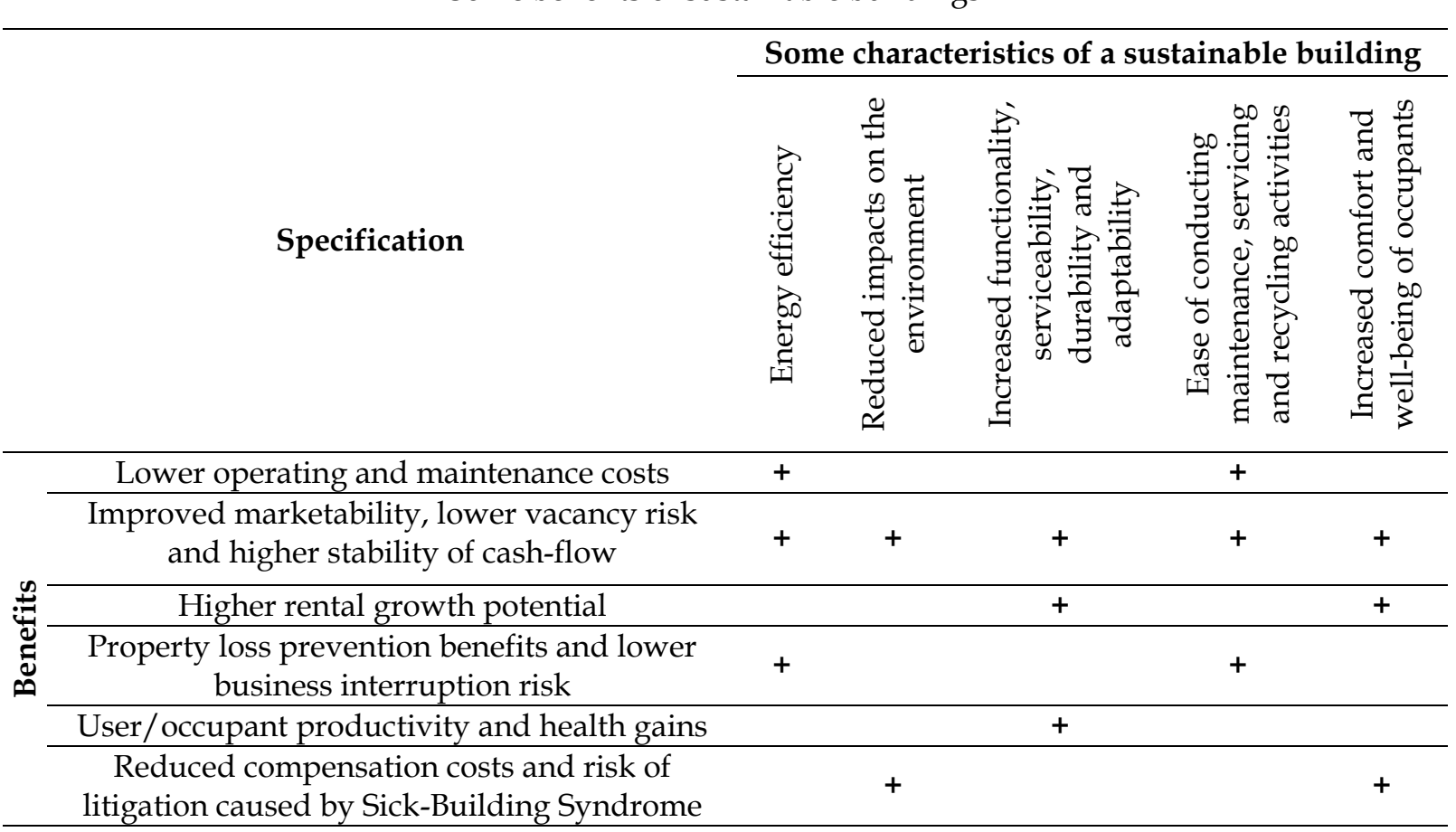

\section{Source: Valuing Sustainability, p. 59.}

Studies carried out in Europe, Canada, the USA, etc., which used revealed preferences or, when unavailable, stated preferences to identify the benefits of sustainable buildings, have revealed that tenants are willing to pay from $2 \%$ to $17 \%$ more in rents for such buildings. They have also shown the costs of operating such buildings to be lower from $6 \%$ to $35 \%$ compared with conventional buildings, as well as reduced non-occupancy rates (BELNIAK et al. 2013, pp. 13-27). This implies that the sustainable characteristics of a building have (or may have) a positive effect on net income and income risk. These benefits should be reflected in the values of properties.

The awareness that the sustainability of a building and its value are positively related to each other led to the emergence of a third area of research assessing the current valuation methods' ability to reflect sustainability in valuations (LORENZ 2006; RUNDE 2015). Sustainable valuation “... is about applying quantitative evidence and qualitative judgement to new value-influencing features and improving market efficiency by providing accurate information to the market place" (VALUING SUSTAINABILITY... 2016, p. 12).

Two categories of valuation methods were subjected to assessment - traditional methods and advanced methods based on the statistical tools - but definite conclusions have not been reached. The EVS promote the income, cost and comparative valuation methods (traditional) (EVS 2016, p. 262). It is considered that the most effective of the three is the comparative method, because it can produce evidence of how much the market would pay for some property's characteristics. The usefulness of the cost, profit and residual methods is sometimes challenged (LORENZ 2006, pp. 172-180), because all

\footnotetext{
4 To remove these barriers, the European Union has financed a training project "RenoValue" for property valuers
} to familiarize them with new valuation requirements (http:// renovalue.eu/). 
three are substitutes for market value estimation. The profit method is deemed inadequate for its focus on the profitability of a business using the property and not on the property itself, and the residual method raises reservations due to the use of uncertain data.

There are also doubts about whether the particular techniques of the income valuation method can quantify sustainability for the purposes of property valuation. The direct capitalization technique is considered inaccurate because it may not correctly estimate the steady income stream from sustainable buildings or the capitalization rate indicating the market's assessment of income risk. The capitalization rate is important because even small variations in its value may have a major impact on the outcome of valuation (MYERS et al. 2007, pp. 8-9). The discounted cashflow (DCF) technique is also disputable. Theoretically, it could reflect sustainability in valuation quite well, but the lack of market evidence prevents it from dealing with this aspect (MYERS et al. 2007, p. 9). It is even posited that none of these techniques can reliably capture the impact of sustainability on the property's value (MYERS et al. 2007, p. 18).

Both academics and practitioners are wary of the use of the advanced valuation methods, as they can produce uncertain results unsupported by the market data (EVS 2016, pp. 262-263). According to the specialists in valuation methodology, they are more appropriate for studying how some properties' characteristics are related to their prices than for valuing properties per se (Lorenz 2006, pp. 164). It is widely held that, to enable the quantification of how sustainability influences the property's value, new data have to be collected, for instance on energy efficiency, etc., or more attention has to be given to market participant behaviors in order to properly assess the marketability, risk and uptake of the property (RUNDE 2015, pp. 144-145). The list of additional, necessary information is long, and in "opaque" markets, most of it may not be available at all.

One of the practical problems that are faced in reflecting the benefits of building sustainability in valuation is that sustainability issues do not exist in isolation but will overlap with other factors (EVS 2016, p. 263). For example, energy efficiency may be a virtue, a cost saving, allow a higher quality of the working environment and be an aspect of a modern building which, as such, has lower maintenance costs or less need of refurbishment. Taken on its own, energy efficiency might not be the decisive factor in value (EVS 2016, p. 263).

\section{The impact of sustainability on the property's value according to earlier research}

Because sustainability may increase the net income stream from a property and reduce income risk, it is reasonable to expect that it may also influence the property's value. To find out if it is really so, numerous studies analyzing the revealed and stated preferences (WTP - willingness to pay) have been conducted. Their results are presented in Table 2.

According to these studies, in both continental Europe and the UK, most respondents believe that sustainability influences the property's price, but this conviction is not supported by solid market evidence. To find out whether such a relationship really exists, long-term research with a large sample of buildings would be necessary. Such studies are still rare in Europe, but first steps have already been taken. For instance, a study analyzing the London office property market in the years 2000-2009 found that sustainable buildings had higher values than conventional ones. However, the limited comparability of these buildings makes the interpretation of the differences between them somewhat problematic. EICHOLTZ et al. (2011, pp. 20-21) noted that the amount of the "green premium" is determined by the number of sustainable buildings in the area and that it falls as competition increases.

Another observation that EICHOLTZ et al. (2011, pp. 24-25) made is that it takes time for the information about property prices to reach the real estate market. Moreover, an initially low volume of transactions may extend the period of high prices because of the limited availability of information and market opaqueness. As more information becomes available, market efficiency is likely to improve.

Because real properties are an investment asset, investors should carefully consider how their value may change in time. Studies show, however, that in predominantly net-lease markets, where the gains from lower operating costs (mainly due to reduced energy consumption) are reaped by the tenants, developers and investors may not be interested in sustainable properties. At the same time, the studies confirm that, if the landlords and owners have fully integrated the potential value of green buildings in their decision making, tenants are still willing to pay the extra cost of going green. This willingness is particularly noticeable in prestigious locations (NAPPI-CHOULET, DECAMPS 2011, p. 23). 
Table 2

Studies of real estate sustainability vis-à-vis its value

\begin{tabular}{|c|c|c|c|c|}
\hline Study by & Year & $\begin{array}{l}\text { Type of } \\
\text { study }\end{array}$ & $\begin{array}{l}\text { Geographical } \\
\text { scope }\end{array}$ & Result \\
\hline $\begin{array}{l}\text { Cushman } \\
\text { \&Wakefield }\end{array}$ & 2007 & survey & Europe & WTP stated by $47 \%$ of respondents \\
\hline $\begin{array}{l}\text { Cushman \& } \\
\text { Wakefield }\end{array}$ & 2009 & survey & Europe & WTP stated by $44 \%$ of respondents \\
\hline Sayce et al. & 2007 & survey & UK & $\begin{array}{l}40 \%(2000) \text { and } 23 \%(2005) \text { of respondents } \\
\text { associate sustainable properties with lower } \\
\text { capitalization rates }\end{array}$ \\
\hline $\begin{array}{l}\text { Fuerst, } \\
\text { McAllister }\end{array}$ & 2008 & regression & USA & $\begin{array}{l}\text { Value of sustainable properties higher by } \\
11-31 \%\end{array}$ \\
\hline $\begin{array}{l}\text { Eichholtz et } \\
\text { al. }\end{array}$ & 2009 & regression & USA & $\begin{array}{l}\text { Value of sustainable properties higher by } \\
6 \%\end{array}$ \\
\hline Miller et al. & 2008 & regression & USA & $\begin{array}{l}\text { Value of Energy Star-certified buildings } \\
\text { and LEED-certified buildings higher by } \\
5.8 \% \text { and } 10 \% \text {, respectively. }\end{array}$ \\
\hline Wiley et al. & 2008 & regression & USA & Higher value of sustainable properties. \\
\hline Pivo, Fisher & 2010 & regression & USA & $\begin{array}{l}\text { Value of sustainable properties higher by } \\
10-16 \%\end{array}$ \\
\hline $\begin{array}{l}\text { Eichholtz et } \\
\text { al. }\end{array}$ & 2010 & regression & USA & $\begin{array}{l}\text { Value of sustainable properties higher by } \\
16 \%\end{array}$ \\
\hline $\begin{array}{l}\text { Dermisi, } \\
\text { Mc Donald }\end{array}$ & 2011 & regression & USA & $\begin{array}{l}\text { Value of the LEED certified buildings } \\
\text { higher by } 23 \%\end{array}$ \\
\hline $\begin{array}{l}\text { Fuerst, } \\
\text { McAllister }\end{array}$ & 2011 & regression & USA & $\begin{array}{l}\text { Value of the Energy Star-certified } \\
\text { buildings and the LEED-certified } \\
\text { buildings higher by } 26 \% \text { and } 25 \% \\
\text { respectively (the amount of premium goes } \\
\text { up with the level of certification) }\end{array}$ \\
\hline $\begin{array}{l}\text { Eichholtz et } \\
\text { al. }\end{array}$ & 2011 & regression & $\begin{array}{c}\text { UK } \\
\text { (London) }\end{array}$ & $\begin{array}{l}\text { Value of the BREEAM-certified buildings } \\
\text { higher by } 26 \%-35 \%\end{array}$ \\
\hline Jaffee et al. & 2011 & regression & USA & $\begin{array}{l}\text { Value of the Energy Star-certified } \\
\text { buildings higher by } 13.4 \%\end{array}$ \\
\hline $\begin{array}{l}\text { Eichholtz et } \\
\text { al. }\end{array}$ & 2011 & regression & USA & $\begin{array}{l}\text { Value of the Energy Star-certified and the } \\
\text { LEED-certified buildings higher by } 13 \% \\
\text { and } 11 \% \text {, respectively }\end{array}$ \\
\hline $\begin{array}{l}\text { Eichholtz et } \\
\text { al. }\end{array}$ & 2013 & regression & $\begin{array}{c}\text { UK } \\
\text { (London) }\end{array}$ & $\begin{array}{l}\text { Value of the BREEAM-certified buildings } \\
\text { higher by } 17 \%-23.5 \%\end{array}$ \\
\hline
\end{tabular}

Note: all results concern the high-transparent markets.

Source: BELNIAK, GŁUSZAK, ZIĘBA, (2013), pp. 23-24 and authors' own study based on a systematic literature review.

According to some market participants, it is more probable that the rents and prices of "unsustainable" properties will be reduced in the long term ("brown discounts") than that sustainable properties will be given "green premiums". This opinion is the most frequent among the German and UK respondents (DRIVERS FOR CHANGE... 2015, pp. 28-31).

\section{Market participants' awareness of the attributes and benefits of sustainable buildings - the case of Poland}

Polish studies dealing with the impact of sustainability on real properties' values are still relatively deficient. Their main focus is on the perception of green buildings and the market participants' knowledge of the costs and benefits of such buildings. The main characteristics of the studies are presented in Table 3. 


\section{S sciendo}

Table 3

Knowledge and perception of sustainable buildings - Polish studies

\begin{tabular}{|c|c|c|c|c|}
\hline Study & $\begin{array}{c}\text { Publication } \\
\text { year }\end{array}$ & $\begin{array}{l}\text { Type of } \\
\text { study }\end{array}$ & Geographical scope & $\begin{array}{l}\text { Study group } \\
\text { (respondents) }\end{array}$ \\
\hline Belniak et al. & 2013 & survey & $\begin{array}{c}\text { Poland } \\
(\text { Krakow, Warsaw })\end{array}$ & $\begin{array}{c}\text { Commercial property experts } \\
\text { in Krakow and Warsaw }\end{array}$ \\
\hline Belniak et al. & 2013 & $\begin{array}{l}\text { survey, } \\
\text { conjoint } \\
\text { analysis }\end{array}$ & $\begin{array}{c}\text { Poland } \\
\text { (Krakow) }\end{array}$ & $\begin{array}{c}\text { Tenants in the office property } \\
\text { market }\end{array}$ \\
\hline $\begin{array}{l}\text { Construction } \\
\text { Marketing } \\
\text { Group, } \\
\text { BuroHappold }\end{array}$ & 2014 & survey & Poland & $\begin{array}{c}\text { Tenants, developers and } \\
\text { investors in the office } \\
\text { property market }\end{array}$ \\
\hline RenoValue & 2015 & $\begin{array}{c}\text { survey, } \\
\text { workshops }\end{array}$ & $\begin{array}{c}\text { Poland, Belgium, } \\
\text { Netherlands, Sweden, } \\
\text { UK, Germany, Italy }\end{array}$ & $\begin{array}{c}\text { Valuers, real estate } \\
\text { consultants, representatives } \\
\text { of banks, construction } \\
\text { companies, investors, } \\
\text { developers, architects }\end{array}$ \\
\hline $\begin{array}{l}\text { Dodge Data } \\
\text { \& Analytics }\end{array}$ & 2016 & survey & $\begin{array}{l}69 \text { countries, including } \\
\text { Poland, Australia, } \\
\text { Saudi Arabia, Brazil, } \\
\text { China, Columbia, } \\
\text { India, Mexico, } \\
\text { Germany, Singapore, } \\
\text { USA, UK }\end{array}$ & $\begin{array}{l}\text { Construction industry } \\
\text { professionals (members of the } \\
\text { Green Building organization), } \\
\text { practitioners }\end{array}$ \\
\hline
\end{tabular}

Source: own study based on a systematic literature review.

The studies found that the real estate market participants in Poland associate sustainable buildings with higher design and construction costs (WORLD GREEN BUILDING TRENDS 2016, p. 30) by an average of $2-10 \%$ compared with conventional constructions (ANALYSING THE SUSTAINABLE... 2014, p. 26). Such buildings are also believed to be energy efficient and, therefore, involve lower operating and technical maintenance costs in the long term, and to offer a high-quality internal environment (ANALYSING THE SUSTAINABLE... 2014, pp. 14-16, WORLD GREEN BUILDING TRENDS 2016, p. 17). Interestingly, in the opinion of real estate market participants in Poland, all these benefits do not translate directly into expectations of lower investment risk (ANALYSING THE SUSTAINABLE... 2014, p. 16).

The studies also showed that tenants from the largest commercial space markets in Poland do not attach much weight to green certificates, concentrating rather on the cost factors (rental and operating costs), the property's location and the quality of space (BELNIAK et al. 2013, pp. 197-202).

There are single cases of tenants in Poland requesting that some specific modifications be made to the property they occupy, probably motivated by the desire to enhance their public image or to meet the ISO standards rather than by the prospects of gaining from sustainable solutions (BELNIAK et al. 2013, pp. 197-202). It has also been observed that the environmental certificates are associated with market advantages rather than with a guarantee of improved energy efficiency of the building. Some market participants go as far as challenging the certification programs and the calculation methods they use, as well as putting to doubt their usefulness as a market tool and a guarantee of higher rents and prices, real estate marketability or improved tenant retention rates (DRIVERS FOR CHANGE... 2015, pp. 50-51, ANALYSING THE SUSTAINABLE... 2014, p. 17, BELNIAK et al. 2013, pp. 197-202).

These findings are contradictory to results of a survey among tenants conducted in the Krakow office space market. This study showed that tenants were willing to pay an average of $12.4 \%$ higher rents for environmentally certified properties as compared with similar but uncertified properties. It needs to be noted, however, that the survey was a quasi-experiment in which the respondents were asked about their hypothetical decisions, which may have influenced its results. Actual behaviours may differ from theoretical choices and the methods of studying stated preferences may result in the overestimation of results (BELNIAK et al. 2013, pp. 214-216, ESV 2016, pp. 185-186). 
International surveys comparing Polish respondents operating in the real estate market with their counterparts from other countries show them to be the least knowledgeable of sustainable building (DRIVERS FOR CHANGE... 2015, p. 29, WORLD GREEN BUILDING TRENDS 2016, p. 30). This statement seems to be equally applicable to tenants in the Polish office market. Average tenants are not cognizant of the real costs and benefits of renting office space in green buildings. A greater awareness of this issue can be found among corporate tenants (BELNIAK et al. 2013, pp. 197-202), particularly international. A similar connection has been noticed in the case of the knowledge of sustainability issues and sustainability rating systems among property valuers. Better knowledge and skills of reflecting sustainability in property valuations was found among valuers working for international corporations, who deal more frequently with clients pursuing CSR strategies and use the opinions' of green building specialists more often. The study results also point to the fact that the real estate specialists' awareness of the benefits of sustainable buildings depends on the availability of market evidence corroborating them (DRIVERS FOR CHANGE... 2015, p. 29).

The low awareness of the benefits of green investments and a lack of political (regulatory) support are indicated as factors obstructing the development of sustainable building in Poland (ANALYSING THE SUSTAINABLE... 2014, pp. 19-20, BELNIAK et al. 2013, pp. 197-202, DRIVERS FOR CHANGE... 2015, pp. 50-51, WORLD GREEN BUILDING TRENDS 2016, p. 19).

The conclusion from the studies is that the main causes of the low awareness of the benefits of environmental certification in Poland are the lack of readily available market evidence and the relatively small number of environmentally certified buildings (ANALYSING THE SUSTAINABLE... 2014, p. 17).

\section{Market participants' perceptions versus market data - the case of Poland}

Because the low awareness of the benefits of going green among the real estate participants in Poland is attributed to the insufficiency of "hard" evidence pointing to the existence of such benefits, a pilot study "Business FOR ClimATE. OPERATING COSTS OF OFFICE BuILDINGS" comparing the consumption of utilities (electricity, etc.) between environmentally certified and uncertified office buildings was conducted with a view to replacing subjective perceptions and opinions with facts.

The study did not find the certified and uncertified buildings to be markedly different regarding the consumption of electricity, but the average use of electricity by offices spaces in the former was found to be lower by $1 / 5$.

The utility water usage was comparatively higher for the certified buildings, but lower, again, when offices spaces alone were considered. The average consumption of heat energy was not a major differentiating factor.

These results were certainly influenced by the short span of the study. Its authors stressed that had they made observations over a longer period, the results would probably have been different. It is also worth noting that installations improving the quality of the work environment increase the consumption of energy and water. This means that a factor in the results could also be improvements made to the internal environment and better building parameters, which is indicated by the authors of the study as quite probable (REPORT BUSINESS FOR CLIMATE... 2016, pp. 10-18). The behaviors of tenants and building administrators can also affect the consumption of utilities. They are sometimes more important than the physical parameters of a building and can cause a certified building to perform below expectations. In such cases, a green certificate is an unfulfilled promise of reduced cost of utilities. The findings of the cited study (weak correlations between the consumption of utilities and green certification, large differences in the use of energy and water between seemingly comparable buildings) appear to confirm that this scenario is plausible (REPORT BUSINESS FOR CLIMATE...2016, p. 22).

It is interesting to note that in the period following the completion of the study, some of the uncertified buildings were certified as sustainable. This shows that studies of this type are faced with a major problem of distinguishing between sustainable and conventional buildings. The authors of the cited study chose green certificates as the differentiating criterion, a solution that is straightforward and easy to use. The problem with this approach, however, is that uncertified buildings may have many green attributes, because many investors build buildings that meet many sustainability criteria for themselves but do not follow through to obtain certification. This questions the usefulness of environmental certificates for drawing the line between sustainable and conventional buildings. 
However, for a lack of other tools such as standard sustainability rating systems, certification is the only available practical criterion for sustainability assessment.

\section{Conclusion}

Developers, property owners, tenants and valuers operating in the Polish real estate market have a limited awareness of the benefits of sustainable buildings and the market itself does not provide solid evidence that such benefits really exist. The probable causes of this low awareness are the relative "opaqueness" of the real estate market, a lack of solid data showing that sustainable buildings can be operated at lower cost, the much belated introduction of sustainable solutions (coal stoves were banned in London as early as 1952), and the favorable attitude that a large share of Poles have for coal as a source of energy. To encourage and promote sustainable building, net leases should be replaced with gross leases so that property owners can reap the benefits of going green ${ }^{5}$.

The market players' low awareness of these benefits and a lack of "hard" market evidence in support of them cause problems with reflecting sustainability in the valuation process. The concept of valuation is founded on the assumption that sustainability will not be reflected in values unless the market provides empirical evidence of its various benefits. The cited studies reveal that also in Europe such benefits are presumed and expected to exist rather than supported by empirical evidence. "Many may say they will pay a premium for meeting certain general standards such as BREEAM, but, as can often be seen in such matters, this may be less evident in actual behavior" (EVS 2016, p. 262). Such things take time to change.

Nevertheless, there is an obvious need to redefine property valuation so that it highlights not only the economic merits of a property but also its environmental, social, ethical and moral attributes. A new type of value must be found, arising from different assumptions than those underpinning the current valuation methods. This opinion is shared by the EUROPEAN VALUATION STANDARDS (2016, p. 261). It does not seem probable, however, that such a new value could be created simply by stretching the current valuation methodology to include new, environmental and social aspects. The reliability of this approach would be questionable. The creation of a new value, wider than the definitional and interpretational framework of market value and embracing what is immeasurable and latent today, but known to exist and to support the environment, would promote the concept of sustainable development and encourage the formulation of responsible real estate strategies. The value would not replace the market value as we know it today, but it would rather enhance it by displaying the competitive advantages of sustainable properties. It would also be an attempt at reconciling economic criteria with social criteria while considering externalities. The concept of this new value draws on the idea of "Creating Shared Value" that has been proposed in literature on this subject, which is considered central to the search for a new value, particularly that - as E. MAcCZYŃSKA stressed (2011, pp. 103-120) - social issues and externalities have apparently not been noticed by valuation criteria so far. The new value breaks with the comfort of considering value only in terms of current profits and widens the economic perspective to include moral and ethical values that go beyond the lifetime of one generation. The comparison of this value for sustainable and conventional buildings will show the amount of value added related to sustainability, i.e. the sustainability premium. Attempts to incorporate various aspects of sustainability have already been made with respect to the product life cycle assessment (LCA), the environmental scope of which is recommended to be extended to economic aspects (Life-Cycle Costing - LCC) and social issues (Social Life Cycle Assessment - SLCA) (TOWARDS A Life CyCle SustainABILITY AsSESSMENT 2011). These three perspectives comprise a comprehensive Life Cycle Sustainability Assessment (LCSA).

Taking a new approach to value is crucial not only for the society, but also for the valuation profession. The specialists in valuation methodology predict that the future of this profession lies in the valuers' ability to quantify relations between humans and their environment (CANNONE, MCDONALD 2003, p. 116). Sustainable valuation should be seen as more an opportunity than a threat to valuers.

The conclusion from the discussion above is that research into the benefits of sustainable buildings should be continued and developed. Future investigations should focus particularly on the evolution of property valuers' awareness and on how its changes influence valuation.

\footnotetext{
${ }^{5}$ A shift towards gross leases can be observed in Australia. See ARMITTAGE 2009, p. 9.
} 


\section{Literature}

Analysing the Sustainable Construction Market in Poland. Market Perception Study, 2014, Construction Marketing Group, BuroHappold.

ARMitAge L., 2009, Thinking about the Value of Property from a Sustainable Perspective, The Australian and New Zealand, Property Journal, No. 2 (1).

BelNiAK S., GŁUSZAK M., ZIĘBA M., 2013, Budownictwo ekologiczne. Aspekty ekonomiczne (Ecological Building. Economic Aspects), Wydawnictwo Naukowe PWN, Warszawa.

BELNIAK S., GŁUSZAK M., ZIĘBA M., 2013, Uwarunkowania ekonomiczne inwestowania w budynki zrównoważone (Economic Conditions of Investing in Sustainable Buildings), Inwestowanie w aktywa rzeczowe i finansowe (Investing in Physical and Financial Assets), Studia Ekonomiczne (Studies in Economics), No. 155, Uniwersytet Ekonomiczny w Katowicach (University of Economics in Katowice).

CANNONE J., MAcDONALD R.J., 2003,Valuation without Value Theory, A North American Appraisal Journal of Real Estate Practice and Education, No. 6 (1), pp. 113-162.

Drivers for Change: Strengthening the Role of Valuation Professionals in Market Transition, Market Insights Report, 2015, RenoValue.

Directive 2012/27/EU of the European Parliament and of the Council of 25 October 2012 on energy efficiency, amending Directives 2009/125/EC and 2010/30/EU and repealing Directives 2004/8/EC and 2006/32/EC.

EichHOLTZ P., KOK N., Quigley J.M., 2010, Doing Well by Doing Good? Green Office Buildings, American Economic Review, no. 100, pp. 2494-2511.

EichHOltz P., KOK N., CheguT A., 2011, The Value of Green Buildings New Evidence from the United Kingdom,

http://immobilierdurable.eu/images/2128_uploads/Chegut_Eichholtz_Kok_green_value_in_the _uk.pdf.

EichHoltz P., KoK N., Chegut A., 2014, Supply, Demand and the Value of Green Buildings, Urban Studies, No. 51 (1), pp. 1-22.

European Valuation Standards 2016, Eighth edition, TEGoVA.

Global Real Estate Transparency Index. Real Estate Transparency. Back on Track, 2012, http://www.joneslanglasalle.co.jp/japan/jajp/Documents/Transparency/JLL_Transparency_2012_E.pdf.

IPCC, Climate Change 2014 Mitigation of Climate Change Summary for Policymakers and Technical Summary, Intergovernmental Panel On Climate Change, 2015.

JaffeE D., StANTON R., WALlaCe N., 2011, Energy Factors, Leasing Structure and the Market Price of Office Buildings in the US, Working Paper, http:// faculty.haas.berkeley.edu/jaffee/Papers/DOE1831.pdf.

KAUKO T., 2013, Education Aspects of Residential Value Analysis Methodology, Norwegian of Science and Technology, In Future Challenges for International Real Estate Education and Practice in 21st Century European Economies. ERES: Education Seminar. Bratislava, Slovakia, https://eres.architexturez.net/doc/oai-eres-id-eres2013-edu-106.

KоŁoDKO G.W., 2014, Nowy paradygmat, czyli ekonomia i polityka dla przysztości (New Paradigm, that is, Economy and Politics for the Future), Ekonomista (Economist), No. 2, pp. 161-180.

LORENZ D., 2006, The Application of Sustainable Development Principles to the Theory and Practice of Property Valuation, Universitäts Verlag Karlsruhe.

MĄCZYŃSKA E., 2011, Gdy stuga staje się panem, czyli dysfunkcje pomiaru wartości biznesu i wyników działalności gospodarczej (When a Servant Becomes a Master, the Dysfunctions of Measuring Business Value and business Performance), Finanse, Rynki Finansowe Ubezpieczenia (Finance, Financial Markets, Insurance), No. 37, pp. 103-120.

Myers G., ReEd R., Robinson J., 2007, The Relationship Between Sustainability and the Value of Office Buildings, 13th Annual Pacific Rim Real Estate Conference.

NAPPI- ChOulet I., DecAmp A., 2011, Is Sustainability Attractive for Corporate Real Estate Decisions?, ESSEC Business School.

NAPPI- CHOUlET I., DeCAMP A., 2012, The Impact of Energy Efficiency and Green Performance on the Value of Corporate Real Estate Portfolio, ERES 2012.

POPKIEWICZ M., 2015, Rewolucja energetyczna. Ale po co? (Energy revolution. But why?), Wydawnictwo SONIA DRAGA Sp. Z o. o., Katowice. 
Report Business for Climate. Operating Costs of Office Buildings, 2016, BuroHappold Engineering, Construction Marketing Group.

RIFFKIN J., 2012, Trzecia rewolucja przemystowa (The Third Industrial Revolution), Wydawnictwo Sonia Draga Sp. Z o. o., Katowice.

RUNDE T.P., 2015, Net Zero Energy Buildings: an Introduction for Valuation Professionals, Appraisal Journal, Spring 2015, pp.141-148.

Towards a Life Cycle Sustainability Assessment, 2011, United Nations Environment Programme, http://www.lifecycleinitiative.org/wp-content/uploads/2012/12/2011\%20\%20Towards\%20LCSA.pdf.

WARREN-MYers G., 2012, The Value of Sustainability in Real Estate: A Review from a Valuation Perspective, Journal of Property Investment and Finance, 30(2), pp. 115-144.

World Green Building Trends 2016: Developing Markets Accelerate Global Growth. Smart Market Report, 2016, Dodge Data \& Analytics.

Valuing Sustainability, 2016, RenoValue, https://pl.scribd.com/doc/312097195/ValuingSustainability-English\#fullscreen $=1$.

ZBIERSKA J., 2007, Geneza idei na rzecz zrównoważonego rozwoju (The Origin of Idea of Sustainable Development), Fragmenta Agronomica 2007 (XXIV), No. 4/96, pp. 275-281 